\title{
Utjecaj onečišćenja zraka na razvoj astme
}

\author{
D. Kučić Grgić,a* K. Karadakić, ${ }^{a}$ S. Majdandžić,a \\ L. Štajduhara i V. Ocelić Bulatovićb \\ a Sveučilište u Zagrebu, Fakultet kemijskog inženjerstva i tehnologije, \\ Marulićev trg 19, 10000 Zagreb, Hrvatska \\ b Metalurški fakultet, Sveučilište u Zagrebu, Aleja narodnih heroja 3, 44 000, Sisak, Hrvatska
}

Ovo djelo je dano na korištenje pod Creative Commons Attribution 4.0
International License

\begin{abstract}
Sažetak
Onečišćenje zraka globalni je problem te se smatra jednim od najčešćih nealergijskih uzročnika astme. Utjecaj onečišćenja zraka na pojavu astme, posebno kod djece, tema je mnogih znanstvenih istraživanja naročito na istoku svijeta s obzirom na problem onečišćenja s kojim se suočava. Ovisno o prostoru djelovanja onečišćenog zraka kojemu je čovjek izložen postoje različite onečišćujuće tvari. Tako onečišćenje zraka u vanjskom prostoru karakterizira izrazita prisutnost ozona, $\mathrm{O}_{3}$, lebdećih čestica, $\mathrm{PM}_{2,5}$ i $\mathrm{PM}_{10}$ te sumporova dioksida, $\mathrm{SO}_{2}$, dok zatvoreni prostori obiluju prisutnošću formaldehida, $\mathrm{CH}_{2} \mathrm{O}$, dušikova dioksida, $\mathrm{NO}_{2}$ i hlapljivih organskih spojeva, VOC. Uz kontrolirano liječenje, velika pažnja se usmjerava i na klimatsko liječenje astme.
\end{abstract}

\section{Ključne riječi}

Astma, lebdeće čestice, klimatsko liječenje astme, onečišćenje zraka

\section{Uvod}

Činjenica da je astma nezarazna, svjetski rasprostranjena, respiratorna bolest koja pogađa preko 300 milijuna ljudi diljem svijeta i da ju nikakvo terapijsko liječenje ne može izliječiti, naglašava važnost identifikacije uzročnika i mjere sprječavanja njezine pojave. Rastući broj istraživanja na svjetskoj razini usmjeren je na pronalazak poveznice između izloženosti onečiščenju zraka i pojave astme. ${ }^{1}$ Dok su neke studije pokazale znatan utjecaj onečišćenja zraka na pojavu astme, drugi nisu pronašli nikakvu vezu između povećanog broja oboljelih od astme i izloženosti onečišćenom zraku. ${ }^{2,3}$

Između različitih onečišćujućih tvari zraka, sitne lebdeće čestice, $\mathrm{PM}_{2,5}$ (engl. particulate matter) najčešće se povezuju s pojavom raznih respiratornih bolesti, jer upravo one mogu zadirati duboko u pluća i prenositi veće koncentracije adsorbiranih i kondenziranih toksičnih onečišćujućih tvari. Stoga je povećana koncentracija sitnih lebdećih čestica, $\mathrm{PM}_{2,5}$, izravno povezana sa slučajevima bolničkog liječenja astme te zaprimanja hitne pomoći uslijed astmatičnog napadaja. Osim njih, veliku zabrinutost i povezanost s hospitalizacijom pokazali su i povećana koncentracija dušikova dioksida, $\mathrm{NO}_{2}$, ozona, $\mathrm{O}_{3}$ sumporova dioksida, $\mathrm{SO}_{2}$ i hlapljivih organskih spojeva, V́OC (engl. volatile organic compounds) u zraku. ${ }^{4,5,6,7}$

Liječenje, točnije ublažavanje simptoma astme uspješno se provodi metodama temeljenim na djelovanju klimatskih uvjeta. Vrlo uspješnim pokazale su se klimatoterapija te talasoterapija, koje se najčešće preporučuju za liječenje te bolesti. ${ }^{8,9}$

\footnotetext{
*Autor za dopisivanje: doc. dr. sc. Dajana Kučić Grgić e-pošta: dkucic@fkit.hr
}

\section{Teorijski dio}

\subsection{Astma}

Astma je kronična, nezarazna upalna bolest dišnih puteva (bronha) koju karakterizira pojačano reagiranje bronha na različite podražaje, a kao posljedica dolazi do bronhoopstrukcije. ${ }^{10}$ Upalu dišnih puteva izaziva imunološki sustav. Astma može biti alergijska i nealergijska, a oba tipa astme liječe se gotovo identično. Razlika je samo u tome što se kod alergijske astme mogu poduzeti preventivne mjere poput prestanka pušenja ili izbjegavanja izloženosti alergenima. ${ }^{11}$ Ovisno o težini bolesti, javljaju se različiti simptomi koji mogu biti prisutni tijekom cijele godine ili periodički. Karakteristični simptomi astme su: kratak dah, otežano disanje, pritisak i bol u prsima, piskanje (zviždanje) u prsnom košu te kašalj, osobito noću i/ili u ranim jutarnjim satima. Pogoršanje astme posljedica je raznih čimbenika, vanjskih (alergeni) kao i unutarnjih (nealergijskih). ${ }^{12} U$ vanjske čimbenike odnosno alergene spadaju: grinje kućne prašine, dlake životinja, pelud drveća i trava i plijesni. ${ }^{13}$ Najčešći unutarnji čimbenici ili nealergijski pokretači astme su: infekcije gornjih dišnih puteva, onečišćenje zraka, pušenje, fizička aktivnost, emocije, stres, hladni i suhi zrak, promjena vremena (promjena temperature i tlaka zraka) i lijekovi (npr. acetilsalicilna kiselina, $\mathrm{C}_{9} \mathrm{H}_{8} \mathrm{O}_{4}$ ). ${ }^{12,14}$

Astma se ne može izliječiti, ali se može uspješno kontrolirati. Da bi se postigla kontrolirana astma, potrebno je redovito uzimati protuupalne lijekove, a najučinkovitiji su inhalacijski kortikosteroidi, čije su nuspojave svedene na minimum. ${ }^{12}$ Oni omogućuju distribuciju lijeka i u niže dišne puteve te tako minimaliziraju simptome bolesti. Redovitim uzimanjem lijekova i izbjegavanjem čimbenika koji pokreću astmu dolazi do smanjenja simptoma i sprječavanja pogoršanja bolesti te se bolesniku omogućuje kvalitetan život. ${ }^{12}$ 


\subsection{Prevalencija astme}

Astma je vrlo važan globalni zdravstveni problem. Procjenjuje se da u svijetu trenutno 300 milijuna ljudi boluje od astme, a do 2020. godine taj broj će, prema procjenama, porasti na 400 milijuna ljudi. Astma se najčešće javlja kod djece, osobito do njihove pete godine života. $U$ dječjoj dobi češće se javlja kod dječaka nego kod djevojčica, da bi nakon 20. godine bila jednako zastupljena u oba spola, a nakon 40. godine bolest je češća kod ženskog spola. ${ }^{11}$

Prevalencija astme u svijetu ovisi o zemljopisnom području, a kreće se između 1 i $18 \%$. Na slici 1 vidimo da najvišu prevalenciju astme nalazimo u Velikoj Britaniji, Novom Zelandu, SAD-u i Australiji. ${ }^{15}$ Činjenica je da sve zemlje s najvećom prevalencijom astme pripadaju engleskom govornom području. ${ }^{16}$ Hrvatska pripada zemljama s niskom do srednje visokom prevalencijom astme, koja je rasla tijekom 2000-ih godina u odnosu na ranija desetljeća te iznosi između 5 i 8 \% kod djece i srednjoškolaca (ovisno o županiji). ${ }^{15}$

\subsection{Povezanost astme i onečišćenja zraka u Hrvatskoj}

U Hrvatskoj 71 mjerna postaja državne i lokalne mreže redovito prati kvalitetu zraka. Premda Hrvatska zahvaljujući okolnostima, a ponajprije stagnaciji gospodarskih aktivnosti i obustavi rada brojnih industrijskih postrojenja, godinama nije na europskoj "crnoj listi" kada je riječ o onečišćenju zraka, pogrešno je zaključiti da Hrvatska uopće nema problem s onečišćenjem zraka. ${ }^{17} \mathrm{U}$ Hrvatskoj je najrašireniji problem onečišćenja zraka lebdećim čestima, $\mathrm{i}$ to ponajprije u pojedinim urbanim područjima u kontinentalnom dijelu zemlje (Zagreb, Sisak, Kutina, Osijek, Slavonski Brod). ${ }^{18,19} \mathrm{U}$ razdoblju od 2013. do 2017. godine u aglomeracijama u Zagrebu i Osijeku te u većim grado- vima industrijske zone - Sisku, Kutini i Slavonskom Brodu - zabilježena su prekoračenja dopuštenih graničnih vrijednosti lebdećih čestica u svim godinama mjerenja, najviše u hladnijem dijelu godine, kada su glavni izvor onečišćenja kućna ložišta, odnosno izgaranje biomase ili drva u kućanstvima, kao i promet.

U lipnju 2019. godine se u Zagrebu, Osijeku i Slavonskom Brodu detektirala povećana koncentracija prizemnog ozona, što je uobičajeno tijekom ljetnih mjeseci i visokih temperatura. Izlaganje prizemnom ozonu može izazvati opasnost za ljudsko zdravlje (glavobolju, iritaciju nosa, grla, dišnih puteva), a u većim koncentracijama može biti i smrtonosan. ${ }^{17,18,20}$ Zrak onečišćen ozonom širi se vjetrom iz urbanih sredina na druga područja, pa u ruralnim područjima koncentracija ozona može biti i veća. Za vrijeme suhih i vrućih dana prizemni ozon se često bilježi na području Primorja, Istre, Like i Dalmacije, jer je ciklus nastanka i razgradnje ozona i njegovih prethodnika ovisan o intenzitetu sunčeva zračenja ${ }^{17}$.

Astma je odgovorna za oko 0,13 \% smrti godišnje u Hrvatskoj, a dobno standardizirana stopa smrtnosti iznosi 0,86/100.000 stanovnika. Provedena su epidemiološka istraživanja astme u Hrvatskoj između 2000. i 2008. godine među školskom djecom u pet hrvatskih županija: Primorsko-goranskoj, Međimurskoj, Požeško-slavonskoj, Brodsko-posavskoj i Gradu Zagrebu. Rezultati pokazuju da je astma najmanje učestala u Međimurskoj županiji, dok je najveći broj oboljele djece bio u Požeško-slavonskoj županiji. ${ }^{21,22}$ Posljednjih godina primijećen je sve veći broj oboljelih od astme, čak $50 \%$ svakih deset godina. ${ }^{15}$ Smatra se da su takvi trendovi posljedica urbanizacije, klimatskih promjena, onečišćenja zraka te zapadnog načina života. ${ }^{23}$ Nažalost, još uvijek nema naznaka da trend oboljelih od astme opada. ${ }^{16}$

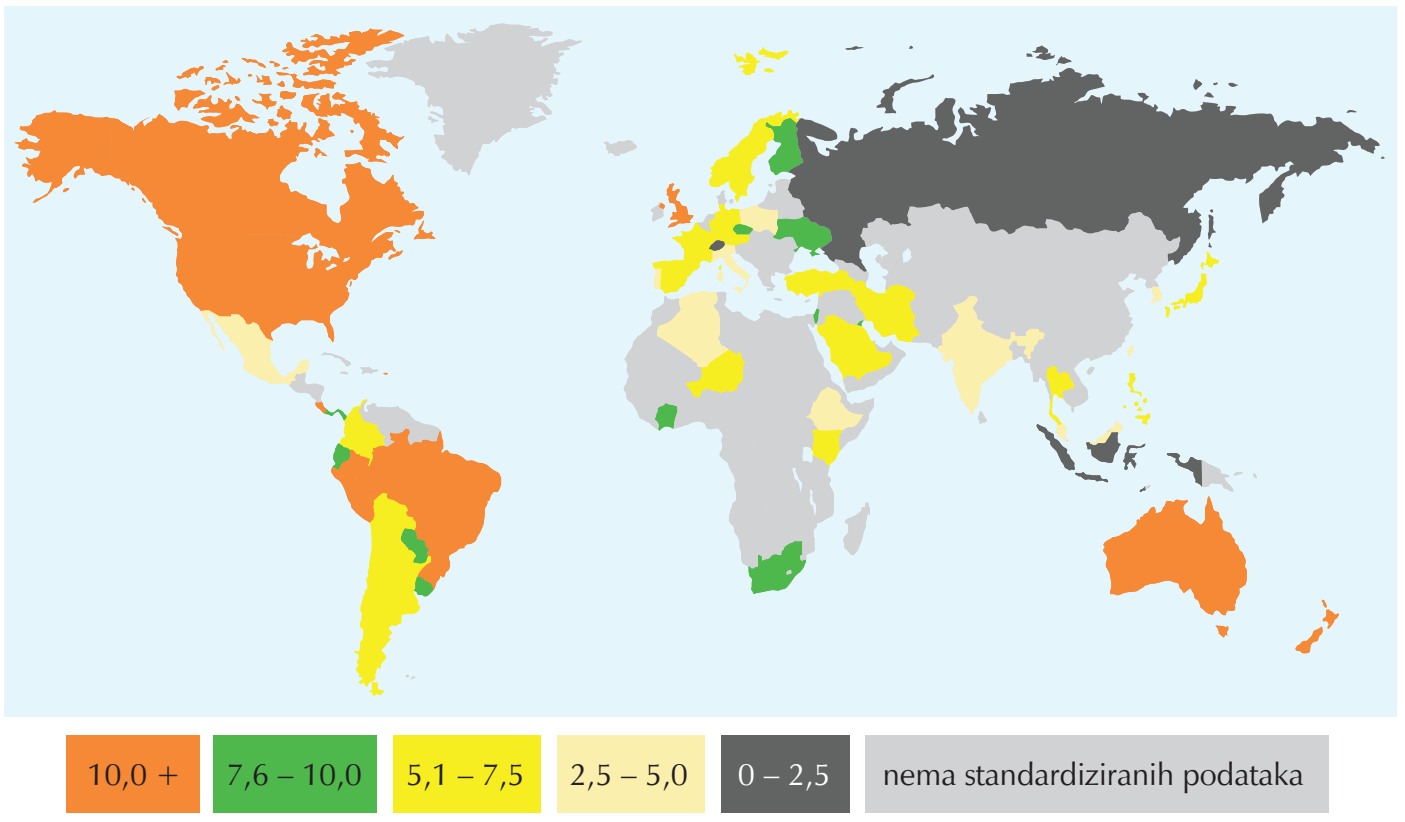

Slika 1 - Postotak populacije sa simptomima astme ${ }^{15}$

Fig. 1 - Percentage of population with asthma ${ }^{15}$ 


\subsection{Povezanost astme i onečišćenja zraka u svijetu}

Silverman i sur. (2010.) proučavali su utjecaj lebdećih čestica, $\mathrm{PM}_{2,5}$ i ozona, $\mathrm{O}_{3}$ na značajnu pojavu astme u New Yorku (SAD). Radili su s četiri grupe: < 6 godina, $6-18$ godina, 19 - 49 godina i 50+ godina. Podatci su sakupljeni iz 74 bolnice smještene u New Yorku tijekom razdoblja od 1999. do 2006. godine. Rezultati su pokazali kako starost oboljelih ima značajnu ulogu. Djeca od 6 do 18 godina pokazala su najveći rizik od oboljenja zbog čega je uočeno povećanje hospitalizacije za tu dobnu skupinu. U njihovoj grupi bio je porast od 26 \% s 95 \%-tnom preciznošću u broju oboljelih kojima je bila potrebna intenzivna njega i 19 \%-tno povećanje u klasičnoj hospitalizaciji za svako povećanje od $12 \mu \mathrm{g} \mathrm{m}^{-3}$ lebdećih čestica, $\mathrm{PM}_{2,5}$. Također, značajan utjecaj lebdećih čestica, $\mathrm{PM}_{2,5}$ i ozona, $\mathrm{O}_{3}$, bio je u ljetnim mjesecima. ${ }^{2,3}$

Ako se pogleda stanje onečišćenja zraka s aspekta prisutnosti lebdećih čestica, $\mathrm{PM}_{2,5}$, na svjetskoj razini može se zaključiti kako su jugoistočna Azija i Afrika najviše pogođene regije. Sukladno tome, problem sve veće pojave respiratornih bolesti u zemljama poput Kine i Japana gorući su izvor zabrinutosti. Procjena stručnjaka jest da se broj slučajeva pojave astme u Kini povećao čak za 40 \% u zadnjih pet godina. ${ }^{7} \mathrm{~S}$ obzirom da je Kina zemlja s najvećom populacijom na svijetu i jedna od najrazvijenijih država, povećanje broja ljudi oboljelih od astme nije neočekivano. Osim onečišćenosti vanjskog zraka, onečišćenje zraka u zatvorenim prostorima jednako štetno utječe na dišni sustav. Zhao i sur. (2007.) usporedili su povezanost simptoma astme sa štetnim utjecajem vanjskog onečišćenog zraka i onečišćenog zraka unutarnjeg prostora. Istraživanje je provedeno na učenicima od 11 do 15 godina starosti u deset škola grada Taiyuan prilikom čega su mjereni parametri onečišćenosti zraka u vanjskim i unutarnjim prostorima. Od ukupnog broja, 1993 sudionika, 1,8 \% je patilo od klasične astme, 8,4\% od hroptanja, a 29,8 \% od svakodnevnih napadaja gubitka daha. Prosječne unutarnje koncentracije sumporova dioksida, $\mathrm{SO}_{2}$, dušikova dioksida, $\mathrm{NO}_{2}$, ozona, $\mathrm{O}_{3}$ i formaldehida, $\mathrm{CH}_{2} \mathrm{O}$ u učionicama bile su 264,8, $39,4,10,1$ i 2,3 $\mu^{-3} \mathrm{~m}^{-3}$. Vanjske koncentracije bile su dva do tri puta veće. Rezultati ispitivanja pokazali su negativan utjecaj sumporova dioksida, $\mathrm{SO}_{2}$, dušikova dioksida, $\mathrm{NO}_{2} \mathrm{i}$ formaldehida, $\mathrm{CH}_{2} \mathrm{O}$ u vanjskom zraku na hroptanje i napadaje gubitka daha očitovan u učestalosti tih simptoma, dok je povišen udio ozona, $\mathrm{O}_{3}$, upućivao na krajnje kritično povećanje dnevnih napadaja ostajanja bez zraka. ${ }^{24}$

U Europi su također provedena ispitivanja kojima se htjela dokazati povezanost između onečišćenja zraka i pojave astme. Martinez-Rivera i sur. (2019.) proveli su istraživanje u Badaloni, Barceloni (Španjolska), gdje se broj hospitaliziranih slučajeva uslijed napadaja astme stavljao u odnos s dnevnim vrijednostima temperature, atmosferskog tlaka, relativne vlažnosti zraka te koncentracijom dušikova dioksida, $\mathrm{NO}_{2}$, sumporova dioksida, $\mathrm{SO}_{2}$ i ugljikova monoksida, CO u zraku. Podatci su sakupljeni u razdoblju od 2008. do 2016. godine. Za statističku analizu primijenjena je jednostavna Poissonova regresija. Bolnička zaprimljenost podijeljena je na hospitalizaciju i pruženu hitnu pomoć. U tom razdoblju hospitalizirana je 1961 osoba (od kojih 1274 žena), a hitna medicinska pomoć pružena je 2431 osobi (od kojih 1315 žena). Prema dobivenim rezultatima, uočava se trend između bolničke zaprimljenosti i niske temperature te povišene koncentracije $\mathrm{NO}_{2}$ u zraku. Broj hospitalizacija povezan je dakle $\mathrm{s}$ niskom temperaturom (lag 0-4) i višim vrijednostima $\mathrm{NO}_{2}$ (lag 0, 1, 2 i 4) kao i broj pružene hitne pomoći (u slučaju niske temperature lag $0-4$, a u slučaju vrijednosti $\mathrm{NO}_{2}$ lag 2,3 i 4). ${ }^{25}$

\subsection{Onečišćenje zraka u zatvorenim prostorima koje uzrokuje astmu}

Urbano stanovništvo većinu svojega vremena provodi u zatvorenim prostorima. Zrak u zatvorenim prostorima onečišćeniji je od vanjskoga i može uzrokovati mnoge zdravstvene probleme. Posebno se to odnosi na bolesti respiratornog i kardiovaskularnog sustava (astma, alergija, ishemijska bolest srca). Onečišćujuće tvari poput formaldehida $\left(\mathrm{CH}_{2} \mathrm{O}\right)$, hlapljivih organskih spojeva (VOC), dušikova dioksida $\left(\mathrm{NO}_{2}\right)$, ugljikova monoksida (CO), ugljikova dioksida $\left(\mathrm{CO}_{2}\right)$, duhanskog dima, lebdećih čestica (PM), bioloških agensa i alergena često su prisutne u zatvorenim prostorijama. ${ }^{23,26}$ Primarni uzrok onečišćenja zraka u zatvorenim prostorima su moderne kuće s neodgovarajućom tj. nepropusnom ventilacijom kako bi se smanjili troškovi grijanja i hlađenja. ${ }^{26}$ Probleme stvaraju i formaldehid i hlapljivi organski spojevi koji se ispuštaju iz novog namještaja, sintetičkih tepiha, boja i građevinskog materijala. Duhanski dim, kuhanje, čišćenje i spaljivanje drva doprinosi značajnom stvaranju lebdećih čestica, koje uzrokuju napade astme i povećavaju smrtnost od respiratornih bolesti. ${ }^{23}$

Viša temperatura i vlaga potiču rast plijesni i grinje kućne prašine. Aspergillus i Penicillium su rodovi plijesni koje su najčešće identificirane u zatvorenom prostoru. ${ }^{23}$ Spore plijesni se prenose zrakom te tako mogu završiti u respiratornom sustavu ljudi. Ostali izvori onečišćenja zraka uključuju plinove od kuhanja i grijanja (dušikov dioksid, ugljikov monoksid), kemikalije iz svijeća i sredstva za čišćenje, onečišćujuće tvari koje ulaze u zatvoreni prostor iz vanjskog okoliša (ozon, lebdeće čestice i itd.) te toksini iz pesticida i osvježivača zraka. Onečišćujuće tvari zraka u zatvorenom prostoru pokazuju sezonske i prostorne varijacije, tako da su zimi povišene razine hlapljivih organskih spojeva, lebdećih čestica i ugljikova dioksida, a ljeti broj bakterija i plijesni uslijed visokih temperatura i vlage. ${ }^{23,26}$

\subsection{Onečišćenje zraka u vanjskom prostoru koje uzrokuje astmu}

Posljednjih godina došlo je do znatnog povećanja onečišćenja zraka usred sve većeg razvoja gradova u svijetu s velikom industrijskom aktivnošću te povećanja broja vozila. ${ }^{27}$ Onečišćujuće tvari zraka oslobađaju se iz mobilnih (cestovna vozila, brodovi i zrakoplovi) i stacionarnih (elektrane, odlagališta otpada, proizvodne industrije, poljoprivreda, vulkani, šumski požari i itd.) izvora. Izlaganje onečišćujućim tvarima zraka, makar i kratkotrajno, izaziva štetne posljedice za respiratorni sustav, što je prikazano u tablici 1. ${ }^{28,29}$ Dokazano je da izloženost onečišćujućim tvarima iz okolnog zraka kao što su ozon, lebdeće čestice $\left(\mathrm{PM}_{2,5}\right.$ i $\mathrm{PM}_{10}$ ), sumporov dioksid i dušikov dioksid pogoršavaju simptome astme. ${ }^{30} \mathrm{Na}$ astmu mogu utjecati na različite na- 
Tablica 1 - Kemijske onečišćujuće tvari i njihov utjecaj na astmu ${ }^{28}$

Table 1 - Chemical pollutants and their impact on asthma ${ }^{28}$

\begin{tabular}{|c|c|c|}
\hline Onečišćujuća tvar & Izvor & Učinak na zdravlje \\
\hline dušikov dioksid & $\begin{array}{l}\text { elektrane, plinske peći za kuhanje, ispušni sustav i drugi } \\
\text { izvori izgaranja fosilnih goriva }\end{array}$ & $\begin{array}{l}\text { akutne i kronične promjene plućne funkcije, } \\
\text { reakcije na alergene kod asmatičara }\end{array}$ \\
\hline ozon & $\begin{array}{l}\text { fotokemijska reakcija dušikovih oksida i ugljikovodika } \\
\text { emitiranih iz vozila i/ili industrije }\end{array}$ & $\begin{array}{l}\text { povećan rizik od upala dišnih puteva i razvoja } \\
\text { astme }\end{array}$ \\
\hline sumporov dioksid & industrijske aktivnosti nakon izgaranja ugljena i nafte & sužava bronhe i utječe na razvoj astme \\
\hline lebdeće čestice & $\begin{array}{l}\text { prirodni izvori kao što su pješčane oluje, vegetacija i/ } \\
\text { ili antropogeni izvori kao što su industrija i emisije } \\
\text { ispušnih plinova iz vozila }\end{array}$ & povećava težinu i učestalost napadaja astme \\
\hline hlapljivi organski spojevi & $\begin{array}{l}\text { vegetacija, emisije ispušnih plinova iz vozila, naftna } \\
\text { i kemijska industrija, kemijsko čišćenje, izgaranje } \\
\text { prirodnog plina itd. }\end{array}$ & $\begin{array}{l}\text { uzrokuje dišne, alergijske i imunološke } \\
\text { probleme kod djece, smanjuje plućnu } \\
\text { funkciju }\end{array}$ \\
\hline
\end{tabular}

čine: kao okidači ili stimulatori, mogu pogoršati postojeću upalu dišnih puteva ili se ponašati kao tvari koje uzrokuju iritacije dišnih puteva. ${ }^{27}$

Udisanje dušikova dioksida vrlo je štetno za rad pluća te povećava rizik nastanka upalnih procesa, a uzrokuje i hiper-reaktivnost na alergene. Taj se spoj može adsorbirati u cijelom respiratornom sustavu, dušniku, bronhima, alveolama i svim ostalim dišnim putevima ovisno o koncentraciji te doziranju. Dovoljno je samo 0,1-0,6 $10^{6} \mu \mathrm{g} \mathrm{m}^{-3} \mathrm{da}$ izazove hiper-reaktivnost na alergene kod čovjeka, a kod jednosatne izloženosti osobe dušikovom dioksidu u koncentraciji od $10 \cdot 10^{6} \mathrm{\mu g} \mathrm{m}^{-3}$ dolazi do povećanja razine proteina i povećane aktivnosti laktat dehidrogenaze, što objašnjava povećanu osjetljivost osobe na alergene. Prema istraživanjima, povećana koncentracija $\mathrm{NO}_{x}$ spojeva u zraku pokazuje znatno veću prevalenciju respiratornih alergijskih bolesti (peludna hunjavica i astma) i veću prevalenciju pokazatelja senzibilizacije (pozitivan prick kožni test na inhalacijske alergene i povišena razina specifičnih IgE-protutijela). ${ }^{31}$

Ozon kao glavna komponenta smoga u nižim slojevima atmosfere vrlo je štetan za zdravlje ljudi, a nastaje fotokemijskom reakcijom dušikovih oksida i ugljikovodika ispuštenih iz vozila i/ili industrije $u$ atmosferi pod utjecajem ultraljubičastog, UV-zračenja. Udisanje ozona može uzrokovati brojne respiratorne probleme poput kašlja, teškog disanja te boli u prsima, a može i povećati rizik od nastanka astme. Većina udahnutog ozona, tj. oko 40 - 60 \% apsorbira se već u nosu, a ostatak prolazi do nižih dišnih puteva. Već nakon šest sati izloženosti ozonu pri koncentraciji od $0,08 \cdot 10^{6} \mu \mathrm{g} \mathrm{m}^{-3}$, kod aktivnih osoba, dolazi do pojave respiratornih problema, a kod izloženosti od 1 do 3 sata (koncentracija $0,40 \cdot 10^{6} \mu \mathrm{g} \mathrm{m}^{-3}$ ) primjećuje se smanjenje aktivnosti dišnih puteva.

Osobe sklone alergijama te astmi vrlo su osjetljive na udisanje sumporova dioksida koji izaziva simptome poput bronhospazma (abnormalnog suženja dišnih puteva), osipa, poremećaja gastrointestinalnog sustava te poremećaje vezane za krvožilni sustav. Kod osoba koje boluju od astme kao i kod zdravih osoba pri desetominutnoj izloženosti sumporovom dioksidu, koncentracije $0,50 \cdot 10^{6} \mu \mathrm{g} \mathrm{m}^{-3}$, dolazi do pojave suženja dišnih puteva. Također, prisutnost sumporova dioksida u zraku povećava mogućnost nastanka sumporne kiseline, $\mathrm{H}_{2} \mathrm{SO}_{4}$, koja se u okolišnom zraku nalazi u obliku aerosola te isto tako povećava rizik nastanka astme.

Lebdeće čestice podrazumijevaju heterogenu smjesu prašine, dima, čađe, teških metala (krom, $\mathrm{Cr}$, bakar, $\mathrm{Cu}, . .$.$) i$ sl. Lebdeće čestice prodiru duboko u pluća te, osim što povećavaju učestalost i težinu napadaja astme, smanjuju i otpornost organizma na razne infekcije. Ispitivanje provedeno u Turskoj pokazalo je da pri povećanju koncentracije lebdećih čestica od $100 \mathrm{\mu g} \mathrm{m}^{-3}$ kod djece koja imaju poteškoće respiratornog sustava dolazi do pojačanja simptoma od čak $139 \%$. Dok je za odrasle, zdrave osobe bila potrebna koncentracija od 400 do $600 \mu^{\prime} \mathrm{m}^{-3}$ lebdećih čestica da bi izazvala probleme s respiratornim sustavom. Dokazano je da lebdeće čestice pojačavaju alergijske upale koje dovode do eozinofilnih upala te hiperplazija. Lebdeće čestice su problematične i zbog toga što adsorbiraju različite alergene koji naravno potiču simptome alergija i astme.

Hlapljivi organski spojevi predstavljaju problem i u zatvorenim kao i u otvorenim prostorima jer se nalaze u tekstilu, namještaju, bojilima, sredstvima za čišćenje, pesticidima i sl. Dokazano je da pojačavaju teško disanje za čak $40 \%$, a simptome astme za $50 \%$. Pri koncentraciji od $2 \mathrm{mg} \mathrm{m}^{-3}$ primijećen je negativan utjecaj na djecu u dobi od 7 do 13 godina koja boluju od astme, a pri koncentraciji između 20 i $50 \cdot 10^{3} \mu \mathrm{g} \mathrm{m}^{-3}$ dolazi do razvoja respiratornih bolesti kod djece. ${ }^{28}$

\subsection{Klimatsko liječenje astme}

Klimatsko liječenje predstavlja pomoćnu metodu liječenja različitih bolesti, a temelji se na djelovanju klimatskih uvjeta na smanjenje simptoma bolesti. Smatra se posebno učinkovitim za liječenje bolesti respiratornog sustava, osobito alergijskih bolesti. U liječenju se primjenjuje klimatoterapija i talasoterapija, odnosno liječenje morskim zrakom i vodom te klimom. Klimatoterapija pridonosi ozdravljenju izbjegavanjem sezonskih alergena tipičnih za kontinentalna područja. Uz to izrazito je bitan čisti zrak, 
povoljno zračno strujanje, optimalna vlažnost zraka, udisanje aerosola koji dolazi do najdubljih predjela alveola, što dovodi do iznimnog fiziološkog učinka te povoljna temperatura zraka i toplina sunčeva zračenja.

Talasoterapija, odnosno primjena morske vode u terapijske svrhe, blagotvorno djeluje na čovjekov organizam. Morska voda potiče izmjenu minerala i toksina između tijela i vode. Oligoelementi i minerali, kao što su magnezij, Mg, mangan, Mn i kobalt, Co, iz mora i zraka potiču obrambenu snagu organizma. Soli i mikroelementi (željezo, Fe, natrij, Na, magnezij, Mg i dr.) koji se nalaze u morskoj vodi djeluju antiseptički, antibakterijski i antivirusno. Primjena klimatoterapije i talasoterapije u liječenju astme utječe na smanjenje upotrebe lijekova, smanjene simptoma i produljenje stabilnih faza bolesti. ${ }^{8,9}$

\subsection{Učestalost pojave astme u dječjem uzrastu}

Astma je najčešća kronična bolest među djecom širom svijeta. Sve veći porast oboljele djece od astme i geografske varijacije u njezinoj prevalenciji proizlazi iz činjenice da onečišćujuće tvari iz zraka utječu na razvoj astme kod djece. ${ }^{30} \mathrm{Na}$ onečišćenje zraka posebno su osjetljiva mala djeca s astmom jer im razvoj pluća nije dovršen, plućni epitel u plućima u razvoju ima povećanu propusnost, imaju nezrele metaboličke puteve i dulje vrijeme provode na otvorenom. ${ }^{32,33}$ Također, mnoge su studije pokazale da je izlaganje policikličkim aromatskim ugljikovodicima, PAH, (eng. polycyclic aromatic hydrocarbon) iz duhanskog dima, ozonu, dušikovu dioksidu, ugljikovu monoksidu i lebdećim česticama u prenatalnom razdoblju, kada su pluća posebno osjetljiva, povezano s pojavom astme $u$ ranom djetinjstvu. ${ }^{34,35}$

\subsection{In vivo testovi toksičnosti onečišćujućih tvari koje uzrokuju astmu i lijekova koji se upotrebljavaju u liječenju astme}

In vivo testovima toksičnosti moguće je ispitati potencijalan negativan učinak određene tvari na ljudski organizam. U takvim testovima toksičnosti prate se fizičke, biološke, kemijske promjene kao i promjene $u$ ponašanju ispitivanog organizma pod utjecajem određene ispitivane tvari. In vivo testovima ispitana je i toksičnost tvari koje uzrokuju astmu tj. tvari koje se upotrebljavaju u liječenju astme.

Riedel $i$ sur. ${ }^{36}$ ispitali su toksičnost sumporova dioksida in vivo testom na zamorcima. Zamorci su bili izloženi uzastopno pet dana, po 8 sati dnevno, konstantnoj koncentraciji sumporova dioksida uz konstantne uvjete vlažnosti i temperature a nalazili su se u komori veličine $20 \mathrm{dm}^{3}$. Posljednja tri dana su nakon izloženosti sumporovu dioksidu, $\mathrm{SO}_{2}$, bili izloženi i 45 min nebuliziranom ovalbuminu. Praćeno je stvaranje antitijela za ovalbumin odnosno bronhijalna reaktivnost kod zamoraca koji su prethodno bili izloženi sumporovu dioksidu u usporedbi s kontrolnom grupom koja nije bila izložena sumporovu dioksidu. Ispitivanje je pokazalo da je kod kontrolne grupe bronhijalna reaktivnost svega $7 \%$, a kod grupe izložene sumporovu dioksidu čak 67 \% tj. sumporov dioksid nadražuje bronhe te može uzrokovati alergijske kao i simptome astme.

Jedni od najučinkovitijih lijekova za liječenje alergijske astme su glukokortikoidi. Jungsuwadee $i$ sur. ${ }^{37}$ ispitali su učinak inhalacijskih glukokortikoida na mužjacima miševa starih šest do osam tjedana. Za potrebe eksperimenta kod miševa je uzrokovana alergijska astma. Ispitivanja su pokazala da su simptomi alergijske astme kod miševa ublaženi kortikosteroidom, deksametazonom, koji je inhibirao lučenje sluzi iz dišnih puteva te smanjio upalu dišnih puteva.

Kod bolesnika s astmom može doći do česte upotrebe agonista beta-2-adrenergičkih receptora, kao što je salbutamol, što može dovesti do pogoršanja simptoma astme. Tamaoki i sur. ${ }^{38}$ ispitali su utjecaj aerosola salbutamola na morfologiju sluznice dišnih puteva, proliferaciju epitelnih stanica dišnih puteva i reaktivnost dišnih puteva kod miševa $\mathrm{u}$ in vivo istraživanju. Rezultati istraživanja pokazali su da dugotrajna izloženost dišnih puteva salbutamolu dovodi do proliferacije epitelnih stanica, zadebljanja stjenke bronha i bronhalne hiper-reaktivnost na metakolin. Dokazano je i da kombinirano liječenje s inhalacijskim kortikosteroidom, budezonidom, može smanjiti bronhalnu hiper-reaktivnost i morfološke promjene sluznice dišnih puteva.

\section{Zaključak}

Astma je jedna od najčešćih bolesti respiratornog sustava, pogotovo kod mlađe populacije. Epidemiološki podatci posljednjih nekoliko desetljeća ukazuju na stalni porast prevalencije astme u svijetu. Smatra se da je sve veći porast oboljelih od astme posljedica okolišnih promjena kao što su: urbanizacija, industrijalizacija, klimatske promjene i onečišćenje zraka. Izloženost onečišćujućim tvarima, pogotovo u duljem razdoblju, poput ozona, lebdećih čestica, hlapljivih organskih spojeva, sumporova dioksida i dušikova dioksida, povezuje se sa simptomima i egzacerbacijom astme, ali i stvara predispoziciju za bolesti respiratornog sustava kod zdravih osoba. Astma je kronična bolest koja se može dobro kontrolirati. Poduzimanjem preventivnih mjera, educiranjem bolesnika i redovitim uzimanjem lijekova smanjili bi se zdravstveni troškovi ali, i što je najbitnije, bolesniku bi se omogućio normalan život bez ograničenja.

\section{Popis kratica}

List of abbreviations

$$
\begin{aligned}
\text { VOC } & \text { - hlapljive organske tvari } \\
& \text { - volatile organic compounds } \\
\text { PM } & \text { - lebdeće čestice } \\
& \text { - particulate matter } \\
\text { PAH } & \text { - policiklički aromatski ugljikovodici } \\
& \text { - polycyclic aromatic hydrocarbon } \\
\text { UV } & \text { - ultraljubičasto } \\
& \text { - ultraviolet }
\end{aligned}
$$




\section{Literatura \\ References}

1. Y. Tian, X. Xiang, J. Juan, K. Sun, J. Song, Y. Cao, Y. Hu, Fine particulate air pollution and hospital visits for asthma in Beijing, China, Environ. Pollut. 230 (2017) 227-233, doi: https://doi.org/10.1016/j.envpol.2017.06.029.

2. R. W. Atkinson, H. Ross Anderson, J. Sunyer, J. Ayres, M. Baccini, J. M. Vonk, A. Boumghar, F. Forastiere, B. Forsberg, G. Touloumi, J. Schwartz, K. Katsouyanni, Acute Effects of Particulate Air Pollution on Respiratory Admissions, Am. J. Respir. Crit. Care Med. 164 (10) (2001) 1860-1866, doi: https://doi.org/10.1164/ajrccm.164.10.2010138.

3. R. A. Silverman, K. Ito, Age-related association of fine particles and ozone with severe acute asthma in New York City, J. Allergy Clin. Immunol. 125 (2) (2010) 367-373, doi: https:// doi.org/10.1016/j.jaci.2009.10.061.

4. M. Lipsett, S. Hurley, B. Ostro, Air pollution and emergency room visits for asthma in Santa Clara County, California, Environ. Health Perspect. 105 (1997) 216-222, doi: https:// doi.org/10.1289/ehp.97105216.

5. W. J. Gauderman, E. Avol, F. Lurmann, N. Kuenzli, F. Gilliland, J. Peters, G. McConnell, Childhood asthma and exposure to traffic and nitrogen dioxide, Epidemiology, 16 (6) (2005) 737-743, doi: https://doi.org/10.1097/01. ede.0000181308.51440.75.

6. S. Lin, X. Liu, L. H. Le, S. A. Hwang, Chronic exposure to ambient ozone and asthma hospital admissions among children, Environ. Health Perspect. 116 (2018) 1725-1730, doi: https://doi.org/10.1289/ehp.11184.

7. J. Watts, Doctors blame air pollution for China's asthma increases, Lancet 368 (9537) (2006) 719-720, doi: https://doi. org/10.1016/S0140-6736(06)69267-2.

8. URL: https://www.plivazdravlje.hr/aktualno/clanak/21837/ Klimatsko-lijecenje-alergija-disnog-sustava.html (29. 3. 2019.).

9. URL: http://www.4seasonscroatia.com/thalassotherapia-crikvenica-snaga-mora-u-lijecenju-disnih-organa/406/ (29. 3. 2019.).

10. F. Pavičić, B. Butorac-Petanjek, S. Popović-Grle, D. Pavičić, Astma u odraslih, u J. Lipozenčić i sur. (ur.), Alergijske i imunosne bolesti, Medicinska naklada, Zagreb, 2011., str. 268.

11. Narodni zdravstveni list, BROJ 694-695/ (2017) studeni / prosinac.

12. I. Gudelj, K. Miše, Smjernice za liječenje astme - uloga IKS-a, Medicus 22 (1) (2013) 13-20.

13. I. V. Yang, C. A. Lozupone, D. A. Schwartz, The environment, epigenome and asthma, J. Allergy Clin. Immunol. 140 (2017) 14-23, doi: https://doi.org/10.1016/j.jaci.2017.05.011.

14. M. A. Tosca, S. Ruffoni, G. W. Canonica, G. Ciprandi, Asthma exacerbation in children: Relationship among pollens, weather and air pollution, Allergol. Immunopathol. 42 (4) (2014) 362-368, doi: https://doi.org/10.1016/j.aller.2013.02.006.

15. S. Popović-Grle, Epidemiologija i značenje astme, Medicus 22 (1) (2013) 7-12.

16. S. Banac, Epidemiološki aspekti alergijskih bolesti u djece, Paediatr Croat. 56 (2012) 71-76.

17. URL: www.haop.hr, Hrvatska agencija za okoliš i prirodu.

18. B. Brkić, Utjecaj onečišćenja zraka u Slavonskom Brodu na zdravlje ljudi i ekosustav, Veleučilište u Šibeniku, Odjel za menadžment, 2018., Šibenik.

19. Zavod za javno zdravstvo Sisačko-Moslavačke županije, Studija procjene mogućeg utjecaja ekoloških čimbenika na zdravstveno stanje stanovništva Sisačko-Moslavačke županije, 2007., Sisak.
20. T. Sofilić, Zdravlje i okoliš, Interna skripta (2015) - Metalurški fakultet, Sveučilište u Zagrebu, Sisak.

21. Lj. Bulat-Kardum, Alergija-moderna epidemija, Medicus 22 (2) (2013) 79-82.

22. A. Stipić-Marković, B. Čvoriščec, Prvi kongres hrvatskih alergologa i kliničkih imunologa s međunarodnim sudjelovanjem, Zagreb, Hrvatska. Zbornik radova, 2009., str. 18-25.

23. C. H. Chen, Y. L. Guo, Asthma: Environmental and Occupational Risk Factors, Encycl. Environ. Health (2018) 238-246, doi: https://doi.org/10.1016/B978-0-12-409548-9.114198.

24. Z. Zhao, Z. Zhang, Z, Wang, M. Ferm, Y. Liang, D. Norbäck, Asthmatic symptoms among pupils in relation to winter indoor and outdoor air pollution in schools in Taiyuan, China, Environ. Health Perspect. 116 (2008) 90-97, doi: https:// doi.org/10.1289/ehp.10576.

25. C. Martínez-Rivera, I. Garcia-Olivé, Z. Stojanovic, J. Radua, J. Ruiz Manzano, J. Abad-Capa, Association between air pollution and asthma exacerbations in Badalona, Barcelona (Spain), 2008-2016., Med. Clin. (Eng. Ed.) 152 (9) (2019) 333-338, doi: https://doi.org/10.1016/j.medcle.2019.02.016.

26. S. Paraschiv, S. Paraschiv Lizica, A review on interactions between energy performance of the buildings, outdoor air pollution and the indoor air quality, Energy Procedia 128 (2017) 179-186, doi: https://doi.org/10.1016/j. egypro.2017.09.039.

27. S. N. Gonzalez-Diaz, A. Arias-Cruz, C. Macouzet-Sanchez, A. B. Partida-Ortega, Impact of air pollution in respiratory allergic diseases, Medicina Universitaria 73 (2017) 212-215, doi: https://doi.org/10.1016/j.rmu.2016.10.006.

28. K. H. Kim, S. Ara Jahan, E, Kabir, A rewiev on human health perspective of air pollution with respect to allergies and asthma, Environ. Int. 59 (2013) 41-52, doi: https://doi. org/10.1016/j.envint.2013.05.007.

29. A. Lewin, S. Buteau, A. Brand, T. Kosatsky, A. Smargiassi, Short-term risk of hospitalization for asthma or bronchiolitis in children living near an aluminum smelter, J. Exposure Sci. Environ. Epidemiol. 23 (2013) 474-480, doi: https://doi. org/10.1038/jes.2013.27.

30. S. Buteau, M. Doucet, L. F. Tétreault, P. Gamache, M. Fournier, A. Brand, T. Kosatsky, A. Smargiassi, A population-based birth cohort study of the association between childhood onset asthma and exposure to industrial air pollutant emissions, Environ. Int. 121 (2018) 23-30, doi: https://doi. org/10.1016/j.envint.2018.08.040.

31. B. Kanceljak-Macan, Alergotoksikologija: Istraživanja utjecaja polutanta na pojavu alergijskih reakcija, Arh. Hig. Rada Toksikol. 61 (2010) 85-94, doi: https://doi.org/10.2478/100041254-61-2010-1942.

32. M. Guarnieri, J. R. Balmes, Outdoor air pollution and asthma, Lancet 383 (2014) 1581-1592, doi: https://doi.org/10.1016/ S0140-6736(14)60617-6.

33. L. Bråbäck, B. Forsberg, Does traffic exhaust contribute to the development of asthma and allergic sensitization in children: findings from recent cohort studies, Environ. Health 8 (17) (2009), doi: https://doi.org/10.1186\%2F1476-069X-8-17.

34. N. Aberle, Utjecaj okoliša tijekom prenatalnog i postnatalnog razdoblja na razvoj respiracijskih bolesti, Paediatr Croat. 58 (1) (2014) 6-12.

35. M. J. Rosa, K. H. Jung, M. S. Perzanowski, E. A. Kelvin, K. W. Darling, D. E. Camann, S. N. Chillrud, R. N. Whyatt, P. L. Kinney, F. P. Perera, R. L. Miller, Prenatal exposure to polycyclic aromatic hydrocarbons, environmental tobacco smoke and asthma, Respir. Med. 105 (6) (2011) 869-876, doi: https:// 
doi.org/10.1016/j.rmed.2010.11.022.

36. F. Riedel, M. Krämer, C. Scheibenbogen, C. H. L. Rieger, Effects of $\mathrm{SO}_{2}$ exposure on allergic sensitization in the guinea pig, J. Allergy Clin. Immunol. 82 (1988) 527-534, doi: https://doi.org/10.1016/0091-6749(88)90961-X

37. P. Jungsuwadee, G. Dekan, G. Stingl, M. M. Epstein, Inhaled dexamethasone differentially attenuates disease relapse and established allergic asthma in mice, Clin. Immunol. 110 (2004) 13-21, doi: https://doi.org/10.1016/j. clim.2003.09.003.

38. J. Tamaoki, E. Tagaya, K. Kawatani, J. Nakata, Y. Endo, A. Nagai, Airway Mucosal Thickening and Bronchial Hyperresponsiveness Induced by Inhaled $\beta_{2}$-Agonist in Mice, Chest 126 (1) (2004) 205-212, doi: https://doi.org/10.1378/ chest.126.1.205.

\section{SUMMARY \\ Impact of Air Pollution on the Development of Asthma

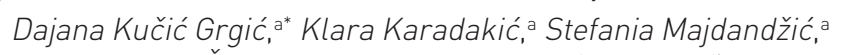 Lucija Štajduhar,a and Vesna Ocelić Bulatovićb}

Air pollution is a global problem and is considered one of the most common non-allergen triggers of asthma. The impact of air pollution on the appearance of asthma, especially in children, is the subject of many scientific researches, especially in the eastern world due to the problem of pollution it is facing. There are different pollutants depending on the area of activity in which a person is exposed. Thus, contamination of outdoor air is characterized by the marked presence of ozone, $\mathrm{O}_{3}$, fine particles, $\mathrm{PM}_{2.5}$ to $\mathrm{PM}_{10}$ and sulphur dioxide, $\mathrm{SO}_{2}$, while indoor air with the presence of formaldehyde, $\mathrm{CH}_{2} \mathrm{O}$, nitrogen dioxide, $\mathrm{NO}_{2}$, and volatile organic compounds, VOCs. With controlled treatment, great attention is focused on climatic treatment of asthma.

\section{Keywords}

Asthma, fine particles, climatic treatment of asthma, air pollution

a University of Zagreb, Faculty of Chemical Engineering and Technology, Marulićev trg 19, HR-10 000 Zagreb, Croatia

${ }^{\mathrm{b}}$ Faculty of Metallurgy, University of Zagreb,

Review

Aleja narodnih heroja 3, 44000, Sisak, Croatia 